\title{
Students' Awareness of Working Life Skills in the United Kingdom, Finland and Germany
}

\author{
Anssi Salonen ${ }^{1}$, Anu Hartikainen-Ahia ${ }^{1}$, Tuula Keinonen ${ }^{1}$, Inês Direito ${ }^{2}$, John Connolly ${ }^{2}$, \\ Annette Scheersoi ${ }^{3}$ and Lara Weiser ${ }^{3}$ \\ ${ }^{1}$ University of Eastern Finland, Joensuu, Finland, ${ }^{2}$ University College London, London, \\ United Kingdom, ${ }^{3}$ University of Bonn, Bonn, Germany
}

Anssi Salonen: anssi.salonen@uef.fi

$+358408251264$

\begin{abstract}
High achievers with low self-efficacy in science lack interest in choosing science studies and careers. Wide-ranging knowledge of specific working life skills in science-related careers can help students identify their own strengths in science. This improves their self-efficacy beliefs in science and further promotes interest in pursuing science studies and careers. The purpose of this paper is to examine lower secondary school students' knowledge of specific working life skills. The participants in this study were 215 British, 144 Finnish and 154 German students, aged 12-14 years. Using open-ended questions and content analysis, we examined students' perceptions of working life skills needed in science-related careers. The results reveal that the students have a great deal of knowledge about working life skills but it is often stereotypical. Students frequently mentioned sector-specific knowledge and personal attributes but skills related to career development, organisation, time and society skills were often omitted. Some variation exists between the countries. The British students linked careers in science with a great deal of thinking skills, whereas the Finnish students emphasised sector-specific knowledge. The German students described the careers more with personal attributes than in the other two countries. We conclude that the students need learning experiences including presentation of working life skills such as interacting with professionals and their real work life problems, open-ended inquiries, and balanced team working. These experiences increase students' awareness and perceived relevance of careers and working life skills, help identifying and promoting own strengths and selfefficacy, and encourage choosing science-related careers.
\end{abstract}

Keywords: working life skills, self-efficacy, science-related careers, lower secondary school, science education 


\section{Introduction}

There is a substantial concern in many countries around the world about a deficiency of professionals working in science (Bøe et al, 2011, OECD 2016). This educational problem has received recognition for decades and industry continue to report a skills gap (European Commission, 2010; Mendick et al., 2017). However, the problem remains. Archer et al. (2014) identified a lack of knowledge about science occupations and negative attitudes behind secondary school students' lack of interest in science-related careers. Moreover, in the same study they found that images and perceptions of scientists influence students' aspirations in science. In addition, STEM career awareness is essential for engagement, self-efficacy and relevance development (Dorsen et al., 2006). Cohen and Patterson (2012) introduced four cognitive-behavioural factors in career development: relevance, engagement, students' career awareness and self-efficacy. The latter two affects students' science-related career choices (Cleaves, 2005) and therefore are particularly relevant for this paper examining students' awareness of science-related careers and particularly knowledge about working life skills and how these are connected with the previous variables.

\section{Career Awareness}

Secondary school students have limited knowledge and understanding of the required competences in STEM careers (Archer et al., 2014; Cleaves, 2005). The limited knowledge is often based on stereotyped perceptions and defective information. These stereotypes might result from low visibility of science-related careers in everyday life (Schütte \& Köller, 2015). In fact, these stereotyped perceptions of science professionals are found in earlier studies including: young children's narratives (Tucker-Raymond et al., 2007); children's constructions of science (Archer et al., 2010); pictures in books (Rawson \& McCool, 2014); and students' perceptions of working life skills needed in science-related careers (Salonen et al., 2017). These perceptions usually describe science and science-related careers as boring, masculine, filled with laboratory work, intellectually demanding, and requiring lots of sectorspecific knowledge. In addition, students have a strong perception that science-related careers are not that creative and social (Masnick et al., 2010). An exception is Andersen et al. (2014) study that found Danish students with high interest in science having informed and realistic image of scientists and that stereotyped perceptions were primarily positive.

During early adolescence, students generally develop vocational identities from detached stereotyped images of work to a more realistic image of themselves at work (Porfeli $\&$ Lee, 2012). However, it seems that conceptions of science-related careers are stable through some of the years of adolescence (Masnick et al., 2010) and lower secondary school science may lead students perceiving that science is not a for them. Without correcting these images and increasing awareness of diverse science-related careers early enough, young students might not want to pursue science studies and careers in the future (Archer et al., 2010). Therefore, students need accurate information about STEM careers, and this information needs to be part of science (Holmegaard et al., 2014).

Science education, particularly in lower secondary school, needs to narrow this gap between students' self-image and the stereotypical beliefs in order to promote STEM studies. For example, science education should help students imagine themselves as agents of scientific activity, including considering what counts as science in and out of school (Bang \& Medin, 2010). Participating in various in- and out of school activities foster students' knowledge of professions and give students possibilities to know and practice their strengths and abilities related with the professions (King \& Glackin, 2010; Wang, 2013). Such activities should include moderately acquired knowledge, linking the career, working life skills and the society together with students' interests, and combining the outside of school activities with the inquiries (Salonen et al., 2018). In addition, students should be encouraged to interpret 
their own experiences, which might be sometimes more important than the actual experiences (Webb-Williams, 2017). These positive school science experiences together with career exploration can raise students' career awareness and sense of self-efficacy.

\section{Working Life Skills and Self-efficacy}

Knowledge about working life skills needed in careers are an essential part of career awareness. Some of these working life skills, sometimes referred as the $21^{\text {st }}$ century skills, could be specific to science-related careers but most of them are generic and transferable between careers. A wide range of studies on $21^{\text {st }}$ century skills all include many of the same skills but categorise them differently (Binkley et al., 2012; P21, 2015; Pellegrino \& Hilton, 2012). When reviewing different $21^{\text {st }}$ century frameworks, Binkley et al. (2012) compiled 10 skill categories: creativity and innovation; critical thinking, problem-solving, decisionmaking; learning to learn, metacognition; communication; collaboration (teamwork); information literacy; ICT literacy; citizenship - local and global; life and career; and personal and social responsibility. They grouped these skill categories into four categories: Ways of thinking, Ways of working, Tools for working and Living in the world. Their framework of $21^{\text {st }}$ century skills includes knowledge, skills and attitudes/values/ethics. Knowledge includes all the specific knowledge or understanding of the skills. Skills are the abilities and processes that develop in students and are a focus for learning. Attitudes, values and ethics describe behaviour and aptitudes in relation to the skills. These $21^{\text {st }}$ century skills are important in STEM careers and students need to develop their sense of self-efficacy in mastering these skills required in STEM careers (Cohen \& Patterson, 2012).

Bandura (1977) defined self-efficacy as a belief of ability to succeed in specific situations or tasks. In his theory, he named four sources of individual's self-efficacy beliefs: performance accomplishments, vicarious experiences, verbal persuasion and physiological states. All of these sources may be promoted in science education. However, performance accomplishments, also known as mastery experiences, are naturally a common part of the learning experiences. According to Bandura, students' may augment sense of self-efficacy during science lessons when successfully performing tasks utilising certain skills. Science education typically involves whole class or group activities, in which students can strengthen their self-efficacy beliefs through vicarious experiences, based on a self-appraisal of their own abilities having observed successful performance by their peers using skills whilst performing varying tasks (Bandura, 1977). Bandura states that verbal persuasion from authorities such as teachers, role models, other adults, or peers can encourage individual's performance. Although physiological feedback, for example stress or relief, may not directly influence on self-efficacy development, but self-efficacy beliefs may be augmented if students feel calm and at ease performing skills and tasks (Bandura, 1977)

Self-efficacy is a key variable in Bandura's (1986) Social Cognitive Theory (SCT), which highlights how learning occurs through behavioural, personal and environmental factors. Lent et al. (1994) extended the SCT with cognitive-person variables such as selfefficacy expectations, outcome expectations and personal goals acting together with a person's environment and, ultimately, impacting on individual's interest and career development. This Social Cognitive Career Theory (SCCT) posits that personal accomplishments in required skills for a profession extends the feeling of self-efficacy to perform in such tasks (Lent \& Brown, 2006). Furthermore, self-efficacy beliefs have an effect on career choice and aspirations, and can be a predictor of career interest (Lent et al., 2010). Students are more likely to pursue a career they perceive themselves to be competent in. Indeed, previous research has revealed that self-efficacy is a significant predictor of students' science performance (Lavonen \& Laaksonen, 2009) and science career aspirations (Kang \& Keinonen, 2017). 
SCCT suggests that environmental and social supports and barriers affect students' career choice interest indirectly through self-efficacy (Lent et al., 2010). For example, students might be less likely to aspire to science-related careers because of the low-visibility of such careers in society or their negative stereotypical perceptions of those careers. Adolescents also lack vivid, clear understanding how these careers can be both socially and personally meaningful and perhaps most importantly, it is unclear to them how their talents and interests can be useful and valuable toward long-term goals (Jahn \& Myers, 2015). Improving students' self-efficacy and skills may need restructuring their cognitive processes relating their own abilities with task performance (Lent et al., 1999). Attempts to foster students' self-efficacy in academic and career-related activities with subject-specific efficacy beliefs should also include a focus on the nurturing and development of self-efficacy in more generic skills such as collaboration and communication skills (Lent et al., 1999). Without promoting students' self-efficacy in a variety of working life skills, students might not see their own abilities important and useful in science and this might have an effect in their future career choices (Cleaves, 2005)

\section{Country Comparison in PISA Context}

PISA 2015 results show that students in Finland are among the top performers in science, and that students in Germany and the United Kingdom (UK) are well above OECD average (OECD, 2016). However, science enjoyment, science self-efficacy and science-related career expectations are much higher among students in the UK than in Finland and Germany. In addition, within the last two factors the change from 2006 to 2015 is positive and over the OECD average only in the UK. Among these three countries, science enjoyment and selfefficacy has dropped the most in Finland. Moreover, PISA results seem to suggest that students in Finland and Germany rarely enjoy acquiring new knowledge and working on science topics. Even though science-related career expectation has risen in all three countries, career aspiration, particularly in science-related careers in the UK, are substantially higher than in Finland and Germany. In OECD countries, on average, $24.5 \%$ of students expect to work in science-related careers, whereas this is the case for $29.1 \%$ in the UK, $17.0 \%$ in Finland and $15.3 \%$ in Germany. Science education has to provide students with learning experiences to acquire knowledge about science-related careers and working life skills. According to SCCT, these learning experiences can develop students' self-efficacy expectations on such skills and later promote students interest towards science studies and science-related careers. PISA 2015 results (OECD, 2016) also reveal some variation in science teaching between these three countries. In the UK and Germany science-related extracurricular activities and enquiry-based teaching are more common than in Finland. These kinds of activities may have positive impact on students' science career choices. Teacher directed science teaching, more common in Finland, has the same positive effect in the UK and Germany, but not in Finland.

\section{Aim of the study and research questions}

Students' career awareness and self-efficacy beliefs are key variables in their future career choices. This study focuses on lower secondary school students' awareness of science-related careers, particularly on the knowledge about working life skills. Moreover, how to relate this awareness with students' self-efficacy in science. Therefore, this study aims to ascertain what kind of skills the students of three different countries link to science-related careers, giving educators a better understanding how to promote science studies and careers more efficiently in science education. This study answers the following two research questions:

What are students' perceptions of working life skills in science-related careers? How these perceptions differ between British, Finnish and German students? 


\section{Method}

The context of this study is the EU project 'Promoting Youth Scientific Career Awareness and its Attractiveness through Multi-stakeholder Co-operation' (MultiCO). MultiCO project's aims are to promote the students' interest in science and their awareness of science career paths and working life skills. The 513 participants in this study were 215 British, 144 Finnish and 154 German students, aged 12-14 years from three different schools participating in the project in each country. During this age in lower secondary school, the students acquire essential information for their later choice of future studies and careers. The students participated in a workshop in which we asked the students in groups of 2-3 persons to write down all the skills needed in a career and to choose the three most important skills from the skills they listed for each science-related careers presented in Table 1. Careers in science (CIS) are the ones involved working in scientific field, working exclusively with science topics. Careers with science (CWS) are the ones that use scientific knowledge or skills as a tool or source for knowledge and skills. For this study, we chose the CIS and CWS from lists of science-related careers so the career pairs are as high in contrast. This encourages students to discuss about the range of different careers. The careers also cover most of the sciencerelated career groups listed in PISA 2015 (OECD, 2016) using International Standard Classification of Occupations (ISCO-08).

Table 1. Career pairs used in the data collection

\begin{tabular}{lll}
\hline & Careers in science (CIS) & Careers with science (CWS) \\
\hline Group 1 & Chemist & Air traffic controller \\
\hline Group 2 & Pharmacist & Software designer \\
\hline Group 3 & Pathologist & Production planner (food industry) \\
\hline Group 4 & Meteorologist & Nurse \\
\hline Group 5 & Geneticist & Horticulturalist \\
\hline Group 6 & Zoologist & Mechatronics mechanic \\
\hline
\end{tabular}

Workshop data was analysed using content analysis, first with the Finnish data (Salonen et al., 2017), and then expanding it with the UK and German data. The analysis included three main phases: the preparation phase, the organizing phase and combining phase (cf. Elo \& Kyngäs, 2008). In the preparation phase, all the Finnish students' answer lists were marked with codes and transcribed. Two authors read the transcriptions and made a decision on analysis based on the data itself. Since the data were mainly a list of skills, there was no need for open coding and it was possible to use the skills as units of analysis. In the organizing phase, the skills were freely categorized and grouped. After using this inductive approach of the content analysis process, a deductive approach with an unconstrained analysis matrix based on Binkley et al. (2012) helped to conceptualize new categories and some categories remained as they were in the analysis matrix. This allowed choosing those aspects that fit into the categorization and use those that did not fit to create one's own categories, based on the principles of inductive content analysis (cf. Elo \& Kyngäs, 2008). The combining phase included sending the analysis instructions based on the Finnish data to the researchers in each country to analyse their data. Then, the first author gathered and combined the data from all the countries and checked that each skill systematically matched with the categories.

\section{Validity, Reliability and Ethical Considerations}

The teachers were instructed to introduce the careers, describing those that were strange and unfamiliar to the students, but not mentioning the skills or abilities necessary to the careers in question. Nevertheless, the teacher's descriptions and help with unfamiliar and difficult careers might have had a minor influence on the students' answers. The workshop with 
teacher's introduction and the students' group work took approximately 45 minutes in total. We enhanced reliability with analysis triangulation (Patton, 1999); in the first phase, two researchers analysed the data separately, ending up with a similar categorization and analysis of the data that ensured the reliability of further analysis. The autonomy of the participant was respected; students' consent was asked and participation was voluntary, giving the students also an opportunity to withdraw from the experiment at any time. Consent was also asked from the parents or their guardians, teachers, schools and/or school administrators. Anonymity of the participants was secured by collecting data anonymously.

\section{Results}

The results include 2487 mentions of the working life skills distributed in 12 skill categories, 4 main categories. We present the students' perceptions of working life skills. First, comparing these perceptions between the countries and finally between careers in science and with science.

\section{Working Life Skills in the UK, Finland and Germany}

The working life skills mentioned by the students were categorised into 12 skill categories and then into 4 main categories: Tools for working, Ways of working, Ways of thinking and Living in the world (c.f. Binkley et al. 2011) introduced in the Figure 1. The students in all three countries, particularly in Finland, pointed out that a great deal of Tools for working skills are necessary in science-related careers. Overall, the students pointed out that a large part of the sector-specific knowledge is needed in all of the careers, with UK and Finnish students mentioning that the sector-specific knowledge was the most needed category in sciencerelated careers. Moreover, Finnish students perceived sector-specific knowledge more necessary their counterparts. In all three countries, the students' perceptions of sector-specific knowledge was focused on school subjects, science and general knowledge. They also perceived sector-specific skills such as scientific, research, manual and technical skills equally important in science-related careers. However, in the UK, the gap between sector-specific knowledge and skills was narrower.

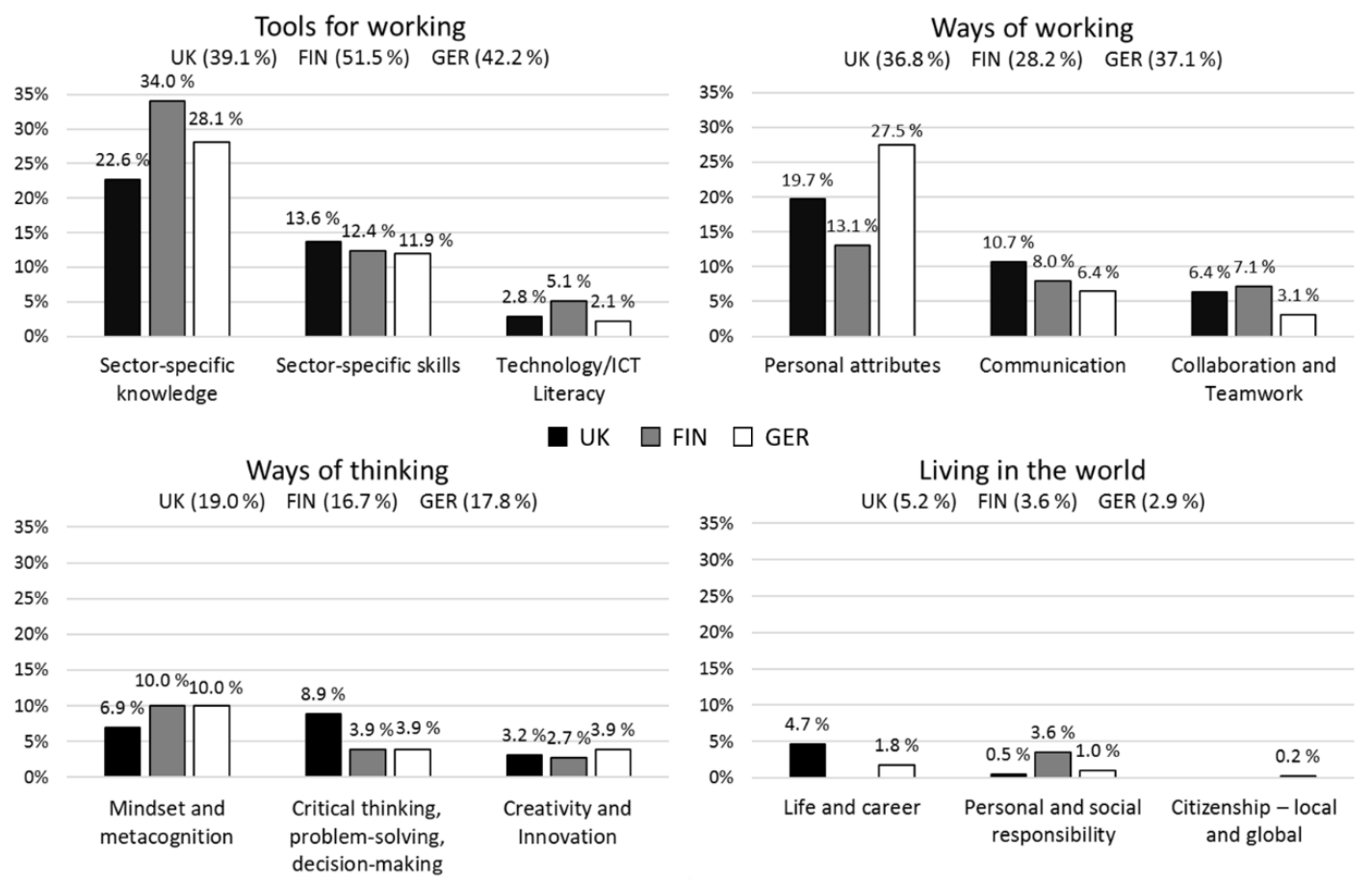

Figure 1. Distribution of the main categories and skill categories in the dataset. 
In the UK and Germany, students perceived Tools for working and Ways of working almost equally important in science-related careers. These students highlighted the Ways of working skills, especially personal attributes, more than Finnish students. In this category, the students described attributes or qualities the person working in a particular career needs such as selfconfidence, patience, good senses and physical condition. According to them, communication skills are more necessary in science-related careers than collaboration and teamwork skills. The students in the UK perceived communication skills more important than in other countries. Conversely, the German students perceived the collaboration and teamwork skills less important. The Finnish students mentioned skills for both categories almost equally. However, some of the communication skills such as getting along with people, and some of the social skills mentioned, were related with co-operative skills and working together with people.

The students listed substantially less Ways of thinking skills than Tools for working and Ways of working although almost equally importantly in all of the three countries. However, some variation in the skill categories existed. For example, Finnish and German students perceived certain mindset and metacognition skills, such as interest on specific scientific field or career, intelligence, focus and good memory, more necessary than the UK students did. Conversely, students in the UK considered critical thinking, problem-solving and decision-making considerably more necessary in science-related careers than their counterparts. According to all students, creativity and innovation skills are not that important in science-related careers. However, some mindset and metacognition skills were marginally related with creativity and innovation skills.

The Living in the world skills with life and career, personal and social responsibility and citizenship skill categories were least mentioned and some of the categories were not mentioned at all across the three countries. Life and career skills, such as organisation skills and adaptation to working environment, were highlighted by the UK and German students but not by the Finnish students. Even though all students perceived personal and social responsibility somehow necessary, Finnish students mentioned these skills more frequently. German students mentioned the only citizenship - local and global skill, ethical consciousness.

\section{Working Life Skills in Careers in Science and Careers with Science}

Some variation becomes obvious when comparing the skills mentioned between the careers in science (CIS) and careers with science (CWS) in total and between the countries (Table 2). In total, students linked CIS more with sector-specific knowledge; personal attributes; communication; collaboration and teamwork; critical thinking, problem-solving, decisionmaking; and personal and social responsibilities. On the other hand, they perceived CWS to be more closely related with sector-specific skills; technology and ICT literacy; and creativity and innovation.

Students in Finland and Germany perceived Tools for working more important in CIS than CWS, whereas students in the UK perceived the opposite. Students, particularly in Finland and Germany, highlighted the importance of sector-specific knowledge in CIS. Conversely, sector-specific skills, and technology and ICT literacy were more important in CWS.

The personal attributes in the category Ways of working were equally associated with both CIS and CWS by the overall sample of students. According to UK students, communication, collaboration and teamwork are needed in CIS more than CWS. Conversely, the German students considered these skills as being needed more in CWS. The Finnish students perceived Ways of working equally important to both career groups. However, they linked communication skills more with CIS and collaboration and teamwork more with CWS. 
Table 2. Distribution of the categories between careers in science (CIS) and careers with science (CWS)

\begin{tabular}{|c|c|c|c|c|c|c|c|c|}
\hline & \multicolumn{2}{|c|}{ UK } & \multicolumn{2}{|c|}{ FIN } & \multicolumn{2}{|c|}{ GER } & \multicolumn{2}{|c|}{ Total } \\
\hline & CIS & CWS & CIS & CWS & CIS & CWS & CIS & CWS \\
\hline Tools for working & $19.0 \%$ & $20.0 \%$ & $28.9 \%$ & $22.6 \%$ & $23.4 \%$ & $18.8 \%$ & $22.3 \%$ & $20.4 \%$ \\
\hline Sector-specific knowledge & $12.4 \%$ & $10.2 \%$ & $22.1 \%$ & $11.9 \%$ & $18.6 \%$ & $9.6 \%$ & $16.0 \%$ & $10.5 \%$ \\
\hline Sector-specific skills & $5.8 \%$ & $7.9 \%$ & $5.3 \%$ & $7.1 \%$ & $4.5 \%$ & $7.4 \%$ & $5.4 \%$ & $7.6 \%$ \\
\hline Technology/ICT Literacy & $0.9 \%$ & $1.9 \%$ & $1.5 \%$ & $3.6 \%$ & $0.4 \%$ & $1.8 \%$ & $0.9 \%$ & $2.3 \%$ \\
\hline Ways of working & $19.7 \%$ & $17.1 \%$ & $14.1 \%$ & $14.1 \%$ & $19.1 \%$ & $18.0 \%$ & $18.3 \%$ & $16.6 \%$ \\
\hline Personal attributes & $10.5 \%$ & $9.2 \%$ & $7.0 \%$ & $6.1 \%$ & $14.8 \%$ & $12.7 \%$ & $10.5 \%$ & $9.2 \%$ \\
\hline Communication & $5.6 \%$ & $5.1 \%$ & $4.3 \%$ & $3.7 \%$ & $2.9 \%$ & $3.5 \%$ & $4.7 \%$ & $4.5 \%$ \\
\hline Collaboration and Teamwork & $3.7 \%$ & $2.7 \%$ & $2.9 \%$ & $4.3 \%$ & $1.4 \%$ & $1.8 \%$ & $3.0 \%$ & $2.9 \%$ \\
\hline Ways of thinking & $10.2 \%$ & $8.7 \%$ & $7.7 \%$ & $9.0 \%$ & $7.6 \%$ & $10.2 \%$ & $9.1 \%$ & $9.1 \%$ \\
\hline Mindset and metacognition & $4.0 \%$ & $3.0 \%$ & $5.1 \%$ & $4.9 \%$ & $4.9 \%$ & $5.1 \%$ & $4.4 \%$ & $3.9 \%$ \\
\hline $\begin{array}{l}\text { Critical thinking, problem-solving, } \\
\text { decision-making }\end{array}$ & $5.9 \%$ & $3.0 \%$ & $2.2 \%$ & $1.7 \%$ & $2.0 \%$ & $2.0 \%$ & $4.2 \%$ & $2.5 \%$ \\
\hline Creativity and Innovation & $0.4 \%$ & $2.8 \%$ & $0.3 \%$ & $2.4 \%$ & $0.8 \%$ & $3.1 \%$ & $0.4 \%$ & $2.8 \%$ \\
\hline Living in the world & $2.7 \%$ & $2.5 \%$ & $2.7 \%$ & $0.9 \%$ & $1.6 \%$ & $1.4 \%$ & $2.5 \%$ & $1.8 \%$ \\
\hline Life and career & $2.5 \%$ & $2.2 \%$ & $0.0 \%$ & $0.0 \%$ & $1.0 \%$ & $0.8 \%$ & $1.6 \%$ & $1.4 \%$ \\
\hline Personal and social responsibility & $0.2 \%$ & $0.3 \%$ & $2.7 \%$ & $0.9 \%$ & $0.4 \%$ & $0.6 \%$ & $0.8 \%$ & $0.5 \%$ \\
\hline Citizenship - local and global & $0.0 \%$ & $0.0 \%$ & $0.0 \%$ & $0.0 \%$ & $0.2 \%$ & $0.0 \%$ & $0.0 \%$ & $0.0 \%$ \\
\hline
\end{tabular}

In total, students linked Ways of thinking skills equally between the careers. Finnish and German students linked specific mindset and metacognition similarly, whereas UK students were more likely to link those skills with CIS. This difference between countries was also found for higher order thinking skills such as critical thinking, problem-solving skills and decision-making which are, according to students, more necessary in CIS. Conversely, for all students, CWS are more linked with creativity and innovation skills.

Living in the world skills were linked only with a few careers. However, there is variation between the career groups and countries. Life and career skills were mentioned by UK and German students only, spreading equally between CIS and CWS. Personal and social responsibilities were mostly linked with CIS by Finnish students, who usually referred to job safety, responsibilities and confidence in other people.

\section{Discussion}

We have identified and categorised the students' perceptions of the working life skills in science-related careers. Our results build up students' point of view on the earlier studies on skills teaching and assessment (Binkley et al. 2012).

The results indicate that students in the UK, Finland and Germany associate working life skills in science-related careers with a large part of Tools for working and Ways of working, particularly sector-specific knowledge and skills, and personal attributes. A possible explanation could be that, in general, traditional science education instruction might give too much focus on activities including theoretical and procedural skills and skills related with acquiring this knowledge (Prince \& Felder, 2013; OECD, 2016). For example learning inquiry skills with precise instructions or memorizing formulae. These performance experiences may disregard the development of self-efficacy of students in other working life skills that are essential in science-related careers and might give unrealistic ideas of CIS. These ideas might lead the students to link these careers with numerous characterizing personal attributes that have been found to be stereotypical in previous studies (Archer et al., 2010; Tucker-Raymond et al., 2007; Salonen et al., 2017).

Science education includes a fair amount of pair and group work which should promote, particularly communication and collaboration skills. However, the small proportion of mentions on communication and collaboration skills, together with the support of an earlier 
study by Lent et al. (1999), highlight the necessity to promote these generic skills together with subject-specific skills. In addition, during opportunities for vicarious learning, each pair or group of students should be equally skilful so that these learning experiences can have the most positive influence on students' self-efficacy (cf. Bandura, 1977) and further develop their outcome expectations that these skills are worthwhile in science-related careers. This is also suggested by the low number of mentions about technology and ICT literacy. Students usually are proficient in and have a high self-efficacy using technology and ICT. However, these skills and tools need to be self-evident or science education would fail to show their importance. Hence, science education should focus on applying technology and ICT more creatively rather than, for example, only for reporting the inquiry results.

Students were less aware of Ways of thinking skills in science-related careers. Particularly Finnish and German students rarely related higher order thinking skills such as critical thinking, problem-solving and decision-making with the science-related careers. These skills are not necessary and thus not promoted in the school context activities and assignments, which might be too closed and include problems set in advance. These assignments can also include strict and detailed instructions with methods, tools and equipment given in advance. This might result in students rarely linking creativity and innovation with scientific careers, thus supporting the study by Masnick et al. (2010). Therefore, school science should include more open problems and open-ended inquiries with less instruction and more student interactions with each other, teacher and most importantly with professionals (Salonen, Kärkkäinen \& Keinonen, 2018; Carlone \& Johnson, 2007) to raise knowledge and self-efficacy in these skills. Without the possibility to make their own decisions and use creativity in science learning, students do not develop a sense of knowing their own strength and abilities in STEM careers (King \& Glackin, 2010; Wang, 2013)

The low percentage of Living in the world skills reveals that students are not yet pondering their future life and careers or responsibilities as active participants in working life or society. Science education should provide learning experiences including wide-ranging issues concerning local, national and global issues. This society participation together with professionals could lead to better understanding of the necessary careers, working life skills and responsibilities in the society. These socio-scientific learning experiences could also include persuasion from professionals as role models or from teachers to promote students self-efficacy beliefs. These experiences increase students' appreciation of one's own and other's opinions, outcome expectations and develop efficacy beliefs in life, career and citizenship skills (cf. Osborne \& Dillon, 2008).

Some variation is obvious in students' perceptions of the working life skills between the career types. For example, CIS are more sector-specific knowledge oriented and CWS skills oriented. In addition, technology and ICT literacy are more important in CWS than in CIS. This skill-orientation could proceed from students having closer relation with CWS, and if these careers are more visible in the society (cf. Schütte \& Köller, 2015). These social supports and barriers affect students' self-efficacy beliefs and subsequently on their perceptions and interests on these careers as proposed in earlier studies Lent et al., 2010).

Even though students perceived Ways of working and Ways of thinking skills almost equally important in both CIS and CWS our results suggest that students link both career types with different type of characteristics including mindsets and personal attributes. These descriptions of the careers align with the earlier studies (Archer et al., 2010; Salonen et al., 2017) finding that students indeed have stereotyped perceptions of scientific careers. In addition, the students linked critical thinking, problem-solving and decision-making more with CIS. Conversely, they linked creativity and innovation skills more with CWS. This supports the earlier study by Masnick et al. (2010) that students do not perceive scientific careers creative. 
The students' knowledge of the working life skills varied only a little between the UK, Finland and Germany. This similarity can result from alike school systems and science education in these countries. However, the students in the UK linked higher order thinking skills with the science-related careers, especially with CIS, considerably more than in Finland and Germany. Reviewing the results in contrast of PISA 2015 results provides interconnections between self-efficacy, career aspirations and enjoyment in science and the students' perceptions of the working life skills. For example, Finnish and German students have lower self-efficacy and career expectations in science than British students (OECD, 2016) and list more sector-specific knowledge and less sector-specific skills, communication skills, and critical thinking, problem-solving and decision-making skills. Finnish and German students rarely enjoying science work and acquiring new scientific knowledge (OECD, 2016) together with perceived large number of sector-specific knowledge leads to lack of engagement in scientific activities (cf. Bang \& Medin, 2010) and further imagining themselves in those occupations.

In sum, science education should include career exploration, open-ended inquiries, interactions between peers and professionals to promote students' career and working life skills awareness, which are essential for self-efficacy and relevance development (Dorsen et al., 2006; Carlone \& Johnson, 2007). These experiences could also promote students' understanding of how their current knowledge and skills are worthwhile (Jahn \& Myers, 2015) and correct misunderstandings related with the science-related careers and the working life skills required in those careers (Archer et al., 2010). Implementing these elements to science education students can have learning experiences with positive effects on their self-efficacy beliefs in working life skills and more probably pursue science studies and careers as students more likely choose a career they perceive being competent in (Lent et al., 2010).

\section{Conclusions}

Results reveal that although the students have a great deal of knowledge about working life skills it is often just stereotypical. They frequently mentioned sector-specific knowledge and skills but omitted skills related to society, organisation, time and career. The students perceived CWS more skill-oriented, creative, innovative, and technology and ICT. Conversely, students perceived CIS as more knowledge-oriented, particularly by Finnish and German students, and requiring more higher order thinking skills by students from the UK and Finland. These differences imply that it is easier for students to relate familiar and practical skills with CWS and list sector-specific knowledge they have learned and, usually stereotyped, characterization with CIS.

Science education, at best, can offer the students with learning experiences promoting wide-ranging knowledge of the science-related careers and the needed working life skills. During these experiences, students' self-efficacy with these skills can develop. The expectations in self-efficacy together with social support from parents, teachers and peers can promote interest in future science studies and careers. Science education activities in and out of school are important sources of students' awareness of careers and required working life skills. Therefore, it is important for educators to be aware of the skills students' link with science-related careers. With this information in mind, they can plan lessons to promote reliable and authentic views of the careers and skills. This kind of teaching helps students to see both, their already acquired and yet to be learned skills more valuable and relevant with science-related careers, school science and science in society. These perceptions, together with the support and feedback from teachers and scientific role models, can increase students' self-efficacy on those skills and further enhance interest on science studies and careers. The EU project MultiCO continues to design, research and provide innovative scientific careerrelated instruction promoting the above. 
For further research, longitudinal studies are implemented about the change and progress in students' awareness of careers and working life skills and what are the students' efficacy beliefs on those working life skills. Future research should concentrate on differences between gender's perceptions of working life skills. Students' career choices might also give more information of what can be done to promote science careers more efficiently and to deliver a more accurate picture about students' science identity, self-efficacy perceptions and role of science and scientific careers in their lives.

\section{Funding}

This project has received funding from the European Union's Horizon 2020 research and innovation programme under grant agreement No 665100.

\section{Disclosure statement}

No potential conflict of interest was reported by the authors.

\section{References}

Andersen, H.M., Krogh, L.B. \& Lykkegaard, E. (2014). Identity Matching to Scientists: Differences that Make a Difference? Research in science Education, 44, 439-460. DOI:10.1007/s11165-013-9391-9

Archer, L., DeWitt, J., Osborne, J., Dillon, J., Willis, B., \& Wong, B. (2010). 'Doing' science versus 'being' a scientist: Examining 10/11 year old school children's constructions of science through the lens of identity. Science Education, 94(4), 617-639. DOI: 10.1080/09500693.2015.1071899

Archer, L., DeWitt, J. \& Dillon, J. (2014). 'It didn't really change my opinion': exploring what works, what doesn't and why in a school science, technology, engineering and mathematics careers intervention. Research in Science \& Technological Education, 32(1), 35-55. DOI: 10.1080/02635143.2013.865601

Bang, M. \& Medin, D. (2010). Cultural processes in science education: Supporting the navigation of multiple epistemologies. Science Education, 94, 1008-1026. DOI: $10.1002 /$ sce. 20392

Bandura, A. (1977). Self-efficacy: Toward a unifying theory of behavioral change. Psychological Review, 84(2), 191-215. DOI: 10.1037/0033-295X.84.2.191

Bandura, A. (1986). Social foundations of thought and action: A social cognitive theory. Englewood Cliffs, NJ: Prentice- Hall, Inc.Bandura, A. (1997). Self-efficacy: The exercise of control. New York: Freeman.

Binkley, M., Erstad, O., Herman, J., Raizen, S., Ripley, M., Miller-Ricci, M., \& Rumble, M. (2012). Defining Twenty-First Century Skills. In P. Griffin, B. McGaw, \& E. Care (Eds.). Assessment and Teaching of 21 st Century Skills (pp. 17-66). Springer.

Bøe, M. V., Henriksen, E. K., Lyons, T., \& Schreiner, C. (2011). Participation in science and technology: Young people's achievement-related choices in late-modern societies. Studies in Science Education, 47(1), 37-72. DOI: 10.1080/03057267.2011.549621

Cleaves, A. (2005). The formation of science choices in secondary school. International Journal of Science Education, 27, 471-486. DOI: 10.1080/0950069042000323746

Cohen, C. \& Patterson, D. (2012). Teaching Strategies that Promote Science Career Awareness., https://www.nwabr.org/sites/default/files/pagefiles/science-careersteaching-strategies-PRINT.pdf . Accessed 25 January 2017. 
Dorsen, J., Carlson, B., \& Goodyear, L. (2006). Connecting Informal STEM Experiences to Career Choices: Identifying the Pathway. ITEST Learning Resource Center. http://stelar.edc.org/sites/stelar.edc.org/files/itestliteraturereview06.pdf. Accessed 25 January 2017

Elo, S., \& Kyngäs, H. (2008). The qualitative content analysis process. Journal of Advanced Nursing, 62(1), 107-115. DOI: 10.1111/j.1365-2648.2007.04569.x

European Commission. (2010). Employers' perception of graduate employability. Analytical report. http://ec.europa.eu/public_opinion/flash/fl_304_en.pdf. Accessed 17 November 2018

Holmegaard, H.T., Madsen, L.M. \& Ulriksen L. (2014). To Choose or Not to Choose Science: Constructions of desirable identities among young people considering a STEM higher education programme. International Journal of Science Education, 36, 186-215. DOI: 10.1080/09500693.2012.749362

Jahn, J. \& Myers, K. (2015). "When Will I Use This?" How Math and Science Classes Communicate Impressions of STEM Careers: Implications for Vocational Anticipatory Socialization. Communication Studies, 66, 218-237. DOI: 10.1080/10510974.2014.990047

Kang, J. \& Keinonen, T. (2017). The effect of inquiry-based learning experiences on adolescents' science-related career aspiration in the Finnish context. International Journal of Science Education, 39, 1669-1689. DOI: 10.1080/09500693.2017.1350790

King, H., \& Glackin, M. (2010). Supporting science learning in out-of-school contexts. In J. Osborne \& J. Dillon (Eds.). Good practice in science teaching: What research has to say (pp. 259-273). Maidenhead, UK: Open University Press.

Lavonen, J., \& Laaksonen, S. (2009). Context of Teaching and Learning School Science in Finland: Reflections on PISA 2006 Results. Journal of Research in Science Teaching, 46(8), 922-944. DOI: 10.1002/tea.20339

Lent, R. W., Brown, S. D., \& Hackett, G. (1994). Toward a unifying social cognitive theory of career and academic interest, choice, and performance. Journal of Vocational Behavior, 45(1), 79-122. DOI: 10.1006/ jvbe.1994.1027.

Lent, R. W., Hackett, G. \& Brown, S. D. (1999). A Social Cognitive View of School-to-Work Transition. The Career Development Quarterly, 47, 297-311. DOI: 10.1002/j.21610045.1999.tb00739.x.

Lent R.W., Brown S.D. (2006). Integrating person and situation perspectives on work satisfaction: A social-cognitive view. Journal of Vocational Behaviour, 69(2), DOI: 236-247. 10.1016/j.jvb.2006.02.006

Lent, R. W., Paixão, M. P., da Silva, J. T., \& Leitão, L. M. (2010). Predicting occupational interests and choice aspirations in Portuguese high school students: A test of social cognitive career theory. Journal of Vocational Behavior, 76(2), 244-251. DOI: 10.1016/j.jvb.2009.10.001

Masnick, A.M., Stavros Valenti, S., Cox, B.D. \& Osman, C.J. (2010). A Multidimensional Scaling Analysis of Students' Attitudes about Science Careers. International Journal of Science Education, 32, 653-667. DOI: 10.1080/09500690902759053

OECD. (2016). PISA 2015 Results (Volume I): Excellence and Equity in Education. Paris: PISA, OECD Publishing.

P21. (2015). Partnership for 21st century skills framework definitions. Retrieved from http://www.p21.org/storage/documents/docs/P21_Framework_Definitions_New_Lo go_2015.pdf

Pellegrino, J. W., \& Hilton, M. L. (2012). Education for life and work: Developing transferable knowledge and skills in the 21st century. Washington, DC: National Academies Press. 
Porfeli, E. \& Lee, B. (2012). Career development during childhood and adolescence. New Directions for Youth Development, 134, 11-22. DOI: 10.1002/yd.20011

Prince, M. \& Felder, R. (2013). Inductive Teaching and Learning Methods: Definitions, Comparisons, and Research Bases. Journal of Engineering Education, 95, 123-128. DOI: $10.1002 / \mathrm{j} .2168-9830.2006 . t b 00884 . \mathrm{x}$

Rawson, C. H. and McCool, M. A. (2014). Just Like All the Other Humans? Analyzing Images of Scientists in Children's Trade Books. School Science and Mathematics, 114, 10-18. DOI: $10.1111 / \mathrm{ssm} .12046$.

Salonen, A., Kärkkäinen, S. \& Keinonen, T. (2018). Career-related instruction promoting students' career awareness and interest towards science learning. Chemistry Education Research and Practice. DOI: 10.1039/c7rp00221a

Salonen, A., Hartikainen-Ahia, A., Hense, J., Scheersoi, A. \& Keinonen, T. (2017). Secondary school students' perceptions of working life skills in science-related careers. International Journal of Science Education, 39, 1339-1352. DOI:10.1080/09500693.2017.1330575

Schütte, K. \& Köller, O. (2015). Discover, Understand, Implement, and Transfer': Effectiveness of an intervention programme to motivate students for science, International Journal of Science Education, 37, 2306-2325, DOI: 10.1080/09500693.2015.1077537.

Tucker-Raymond, E., Varelas, M., Pappas, C. C., Korzh, A., \& Wentland, A. (2007). "They Probably Aren't Named Rachel": Young Children's Scientist Identities as Emergent Multimodal Narratives. Cultural Studies of Science Education, 1, 559-592. DOI: $10.1007 / \mathrm{s} 11422-006-9017-\mathrm{x}$

Wang, X. (2013). Why students chose STEM majors: Motivation, high school learning, and post-secondary context of support. American Educational Research Journal, 50(5), 1081-1121. DOI: $10.3102 / 0002831213488622$

Webb-Williams, J. (2017). Science Self-Efficacy in the Primary Classroom: Using Mixed Methods to Investigate Sources of Self-Efficacy. Research in Science Education. DOI $10.1007 / \mathrm{s} 11165-016-9592-0$ 